\title{
IMPROVEMENT STUDENT COOPERATION USING COOPERATIVE LEARNING MODELS OF NUMBERED HEADS TOGETHER (NHT) TYPE ON VIII GRADE STUDENTS OF SMP MUHAMMADIYAH 2 MINGGIR SLEMAN
}

\author{
Andri Wijaya ${ }^{\mathrm{a}}$, Suparyan ${ }^{\mathrm{b}}$ \\ Mathematics Education Study Program of FKIP UAD \\ Jln. Ringroad Selatan, Tamanan, Banguntapan, Bantul, Yogyakarta \\ awijayamath@gmail.com, ${ }^{b}$ suparyan.uad@gmail.com
}

\begin{abstract}
Cooperation of students while following the process of mathematics is still lacking. Using a cooperative learning model with the type of $N H T$ expected to improve cooperation of students in particular on VIII grade student of SMP Muhammadiyah 2 Minggir Sleman in odd semester of the academic year 2015/2016. The purpose of this study is to improve cooperation students in learning mathematics using a cooperative learning model with the type of NHT VIII grade of students SMP Muhammadiyah 2 Minggir Sleman in odd semester of the academic year of 2015/2016. The research is classroom action research. The subject of the is VIII grade students of SMP Muhammadiyah 2Minggir Sleman in odd semester of an academic year of 2015/2016. The object of the research is the cooperation improvement of student's mathematics in learning to use the cooperative learning model with the type of NHT. The study is done in two cycles. Data were collected by using observation sheets, interview sheets and daily tests which had reviewed by supervising lecturer, mathematics teachers, and had been validated by the lecturer expert. An analysis of the data is used was descriptive analysis qualitative. The result showed that the cooperative learning model with the type of NHT can improve the cooperation of students in grade VIII of SMP Muhammadiyah 2 Minggir Sleman in odd semester of the academic year 2015/2016. This comes from the observation of student's cooperation on each cycle that had been increased, namely the percentage of student's cooperation cycle I worth 57,29\% with criteria of enough, and in cycle II increase to $71 \%$ with the criteria of good.
\end{abstract}

Keywords: Classroom action research, cooperation, Numbered Heads Together (NHT)

\section{INTRODUCTION}

Becoming an advanced nation is certainly an aspiration to be achieved by every country in the world. A nation can be measured whether the nation is advanced or not influenced by educational factors. Therefore the Indonesian government has several efforts to improve the quality of human resources, one of which is an improvement in the education sector. In the National Education System Law No. 20 of 2003 Chapter II Article (3) states that national education has the function of developing capabilities and forming dignified national character and civilization in order to educate the nation's life, aiming at developing potential students to become believers and godly people, moral noble, healthy, knowledgeable, capable, creative, independent and a citizen of a democratic and responsible state.

From the objectives of national education, it is clear that the role of education is very much needed by humans since he was born to death (life long education). In addition, the role of education is very large in advancing a nation to obtain intelligent and independent human resources. Therefore, improving the quality of education is very important to anticipate the development of science and technology that is growing rapidly. The learning process is expected to be carried out interactively, inspiring, fun, challenging and motivating students to actively participate, as well as providing sufficient space for initiatives, creativity, and independence in accordance with talents, interests and physical development, as well as the psychology of students. Therefore the need to establish a learning atmosphere that establishes student cooperation so that they can communicate with each other, motivate each other and can play an active role in learning.

Based on information obtained from class VIII teachers of SMP Muhamamdiyah 2 Minggir Sleman Regency, most students pay less attention to the material delivered by the teacher, students tend to be silent and shy about asking when there is material that is not understood, students are easily discouraged when working on difficulties confident in solving questions because students are not familiar 
with the material, students have not helped each other when experiencing difficulties in learning mathematics and students are less active in learning. This was evidenced when the researcher conducted an interview with the mathematics teacher on November 25, 2014, in class VIII of SMP Muhamamdiyah 2 Minggir Sleman Regency. The teacher said that in learning mathematics, students were less active and enthusiastic in learning mathematics. When you encounter a problem that is difficult, just stay quiet, do not want to ask a friend or teacher. When given group assignments by the teacher, students have not helped each other yet, some students prefer to work on their own. So that student collaboration in learning mathematics in class VIII is still low.

Based on the documentation results also obtained data that the mathematics learning outcomes of class VIII in SMP Muhamamdiyah 2 Minggir Sleman Regency is still low. This can be seen from the midterm test scores of students in mathematics while there are still many students who score $<75$ which is below the minimum completeness criteria (MCC) value of mathematics in SMP Muhammadiyah 2Minggir Sleman Regency. The low student learning outcomes are shown in Table 1 below:

Table 1. The midterm test scores of students in the mathematics of Class VIII in SMP Muhamamdiyah 2 Minggir Sleman Regency

\begin{tabular}{|l|c|c|c|c|}
\hline \multirow{2}{*}{\multicolumn{1}{|c|}{ Class }} & \multicolumn{3}{|c|}{ VIII } & \multirow{2}{*}{ Total } \\
\cline { 2 - 4 } & $\mathrm{A}$ & $\mathrm{B}$ & $\mathrm{C}$ & \\
\hline Complete MCC & $0 \%$ & $12,5 \%$ & $0 \%$ & $4,17 \%$ \\
\hline Not Complete MCC & $100 \%$ & $87,5 \%$ & $100 \%$ & $95,83 \%$ \\
\hline Total & $100 \%$ & $100 \%$ & $100 \%$ & $100 \%$ \\
\hline The highest score & 7,33 & 8,67 & 5 & 7 \\
\hline Lowest score & 2,33 & 3,33 & 0 & 1,89 \\
\hline
\end{tabular}

(Source: SMP Muhamamdiyah 2 Minggir from 2015/2016 Academic Year)

From Table 1 above, it can be seen that the majority of class VIII students do not complete MCC. of grade VIII students only $4.17 \%$ of students completed MCC. This proves that mathematics subjects have not been mastered by all students. Seeing this phenomenon, it is necessary to apply a learning system that involves students actively in teaching and learning activities to improve student collaboration in learning mathematics in the classroom. One model of learning that involves students actively is a cooperative learning model. Through this learning model, students can express the results of their thoughts, exchange opinions, cooperate with each other when there are friends in the group who experience difficulties.

Based on students' mastery of mathematical material, in this study, the learning model chosen was the Numbered Heads Together (NHT) type of cooperative learning model. In this model students are very dominant in the learning process and the occurrence of cooperation in groups with characteristics 1) heterogeneous groups, 2) have different head numbers, 3) think together (Head Together), so that all students try to understand each material taught and responsible for the number of each member. With the selection of this model, it is expected that learning can be more interesting, meaningful and give a strong impression to students.

Based on the background above the author identified the problem in this study as follows.

1. Some students pay less attention when the teacher is delivering the material.

2. Students tend to be silent and shy about asking other friends or teachers when there is material that has not been understood.

3. Students have not helped each other and prefer to work on their own when given group assignments by the teacher.

4. Most students in mathematics subjects have not yet reached the MCC score.

5. Lack of student collaboration in mathematics learning.

The problems in this study can be formulated as follows. Does using the NHT type of cooperative learning model improve student collaboration in mathematics learning in class VIII SMP Muhamamdiyah 2 Minggir Sleman Regency in odd semester 2015/2016 academic year?. The purpose of this study is to 
improve student cooperation in mathematics learning in class VIII of SMP Muhamamdiyah 2 Minggir Sleman Regency in odd semester of 2015/2016 academic year using the NHT type cooperative learning model.

\section{METHODS}

This research is a type of class action research (CAR) which is a study conducted in the classroom. According to Arikunto, Suharsimi, Suhardjono and Supardi (2007: 3) classroom action research (CAR) is an examination of learning activities in the form of an action, which is deliberately raised and occurs in a class together. The action is given by the teacher or by the direction of the teacher conducted by the student. According to Arikunto, Suharsimi, Suhardjono and Supardi (2007: 16-19) in general there are 4 stages that are commonly passed, namely (1) planning, (2) implementation (action), (3) observation (observation) and (4) reflection. The procedure for classroom action research consists of three cycles each cycle including:

\section{a. Planning}

In this stage, the researcher explains what, why, when, where, by whom, and how the action was carried out. Activities carried out at the planning stage are compiling plans to be carried out, in accordance with the provisions of the problem and initial ideas. The design to be carried out refers to the NHT type cooperative learning model. In this planning, the researcher develops the learning implementation plan and the observation sheet.

\section{b. Implementation of actions}

At this stage, the teacher implements the NHT type cooperative learning design as planned. In an effort to improve, a flexible plan is ready to make changes according to what happens in the implementation process in the field.

\section{c. Observation}

This observation is carried out during the implementation of the action as an effort to find out the course of learning. In making observations, researchers are assisted by other observers who take part in observing learning based on observation guidelines prepared by researchers.

\section{d. Reflection}

At this stage, the researcher discusses with the teacher about the results of the observations made, the shortcomings and achievements of the learning to conclude the data and information that have been collected as consideration for the next cycle of learning planning. If based on this reflection repetition is needed, the cycle can be repeated again.

The research flow of class action (Arikunto, Suharsimi. 2013: 137) is as follows.

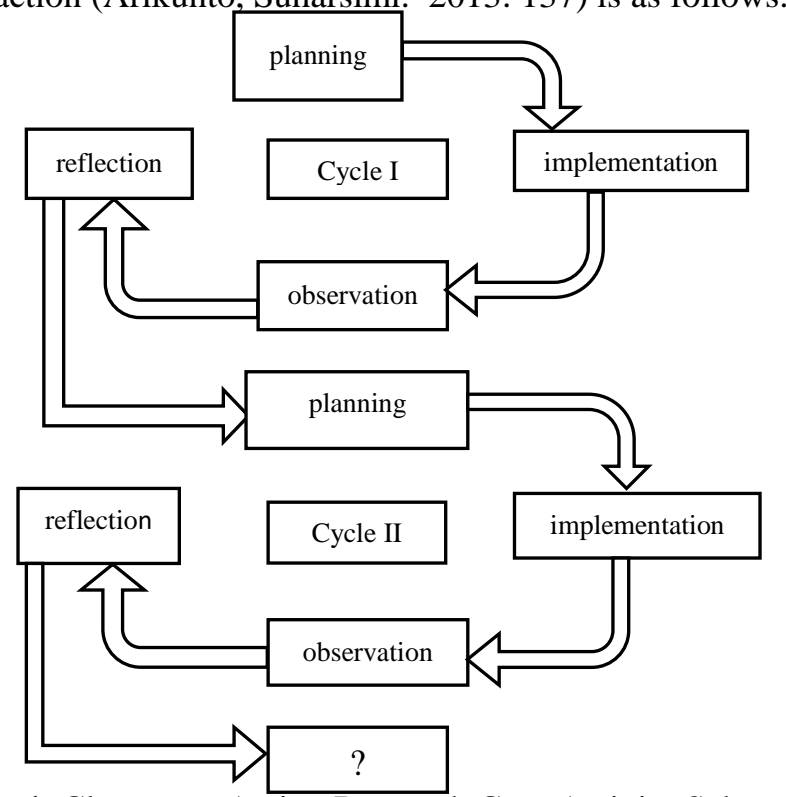

Picture 1. Classroom Action Research Core Activity Scheme 
The cycle is stopped if learning with the NHT type of cooperative learning model has increased student collaboration and achieved minimum B criteria (good). The subjects in this study were class VIII C SMP Muhammadiyah 2Minggir Sleman Regency, the object in this study was to increase student collaboration in mathematics learning using the NHT type cooperative learning model.

The research procedure can be explained as follows:

\section{Cycle I}

a. Planning I

At this stage the researcher designs the actions to be taken in the research, namely:

1) Prepare material that is taught and search for materials that support the subject matter.

2) Make a learning implementation plan (action plan) about the material to be taught in accordance with the steps of the NHT type cooperative learning model.

3) Compile head and group numbers

4) Researchers and teachers collaboratively prepare learning resources.

5) Making questions (students worksheet) as material for group discussion

6) Prepare research instruments which include student cooperation observation sheets, interview sheets, and teacher activity observation sheets.

7) Prepare documentation tools.

b. Implementation I

The implementation carried out is the implementation or implementation of the contents of the design that has been made, namely conducting classroom learning. At this stage of implementation, the implementation was carried out by researchers who acted as mathematics teachers in class VIII C and conducted learning in the classroom using the NHT type cooperative learning model.

c. Observation I

Observation or observation is one of the research data collection techniques regarding the ongoing learning process. Observations are carried out by researchers and assisted by other observers, namely mathematics teachers who also observe the implementation of the action using the prepared observation sheet. Observations were made during the implementation of the action in an effort to find out the course of learning. At this stage, the group and inter-group collaboration in the learning process were observed using the NHT type of cooperative learning model, learning activities and obstacles encountered during the implementation of learning which will then be analyzed at the reflection stage. At the last meeting in the first cycle after observations were given a test (daily test) in the form of questions describing the material that had been given which was done individually to determine students' understanding of the material, they had learned.

d. Reflection I

From the data that has been obtained during the observation of the researcher collaboratively with the subject teacher evaluating and implementing corrections from the observations that have been given to take the next step. From these results, it is seen whether it has fulfilled the expected goals in the process of cooperation in learning. If you have fulfilled the goal, this research is stopped. But if it does not meet the objectives, then the research continues to the next cycle. The purpose of this reflection is to evaluate the learning process that has been carried out in the first cycle to find out the strengths and weaknesses. So that it can be an evaluation material for improvement in cycle II.

\section{Cycle II}

a. Planning II

At this stage, the learning activities are re-planned which refers to the results of the first cycle with the aim of improving deficiencies and increasing the success achieved in the first cycle. In this second cycle researchers designed learning using the NHT type cooperative learning model. Planning in cycle II is not much different from planning in cycle I. 
b. Implementation II

The implementation of the action in the second cycle is not much different from the implementation of actions in the first cycle, except that it refers to several improvements that have been formulated in the planning, carried out several revisions based on reflection in the first cycle in order to better enhance student cooperation.

c. Observation II

Observation in the second cycle is almost the same as the observation in the first cycle, namely the observation of student collaboration in the learning process by using the NHT cooperative learning model, and the obstacles encountered during the implementation of the action. This observation is also given a stage II test (daily test).

d. Reflection II

At this stage, discussions were held between researchers and mathematics teachers regarding the results obtained at the observation stage as was done in cycle I. From these results it was seen whether student learning cooperation had increased compared to the first cycle or not. If you have met the objectives, the research is considered complete and complete according to the plan. If the goal has not been achieved then the cycle III, IV, and so on will be possible if the results of the second cycle still have many shortcomings or have not reached the predetermined indicators of success.

\section{Cycle III}

In the third cycle, the same steps were carried out as carried out in cycle I and cycle II which included planning, implementation, observation, and reflection. The planning carried out is based on the results of the second cycle of reflection. Cycle III aims to find out the results of a cycle I and cycle II with the results obtained in cycle III whether there is an increase in student collaboration in the learning process of mathematics or not. Then from the results of learning using the NHT learning model conclusions are taken so that they can know whether there is an increase or not. However, if in the first cycle and second cycle there is an increase then the third cycle is not mandatory.

Data collection techniques used in this study were observation, interviews, documentation, and triangulation. While the data collection instruments in this study are observation sheets and interview sheets. Data analysis using descriptive analysis, namely observation data is calculated using the percentage formula:

$\mathrm{NP} \quad=$ percent value sought or expected

$$
N P=\frac{R}{S M} \times 100
$$

$\mathrm{R} \quad=$ raw scores obtained by students

$\mathrm{SM}=$ ideal maximum score of the indicator component of cooperation

$100=$ fixed number

(Purwanto, M. Ngalim. 2013: 102)

The results of the percentage criteria can be seen in Table 2 below:

Tabel 2. Percentage Criteria for Student Collaboration and Teacher Activities

\begin{tabular}{|c|c|}
\hline Percentage (\%) & Criteria \\
\hline $80<\mathrm{NP} \leq 100$ & Very well \\
\hline $60<\mathrm{NP} \leq 80$ & Well \\
\hline $40<\mathrm{NP} \leq 60$ & Enough \\
\hline $20<\mathrm{NP} \leq 40$ & Less \\
\hline $0 \leq \mathrm{NP} \leq 20$ & Less once \\
\hline
\end{tabular}

(Arikunto, Suharsimi dan Cepi Safruddin Abdul Jabar (2014: 35)

The indicator of success in this study is if the percentage of student collaboration reaches $>60 \%$. 


\section{RESULTS AND DISCUSSION}

This classroom action research was conducted at SMP Muhammadiyah 2 Minggir Sleman Regency on 30 October 2015 until 7 November 2015. SMP Muhammadiyah 2 Minggir Sleman Regency has 3 classes VIII, namely class VIII A, VIII B, and VIII C. Action research The class was held in class VIII C with a total of 26 students consisting of 16 male students and 10 female students. In this class action activity, the researcher acts as a teacher and in carrying out the learning process uses the NHT type cooperative learning model, while the teaching teacher/class teacher acts as an observer. This research was conducted in 2 cycles consisting of 2 meetings for each cycle, with details of the first and second meetings discussing the material and at the end of the second meeting a daily test was held.

This research was conducted according to the mathematics schedule of class VIII C. The study was conducted on Friday and Saturday in 4 meetings consisting of 2 cycles. Each cycle is carried out in 2 meetings, and each meeting has a time allocation of $2 \times 40$ minutes.

The results of class action research were conducted at Muhammadiyah Middle School 2 Minggir Sleman Yogyakarta Regency which consisted of the cycle I and cycle II. In observing the first cycle of the first meeting it was seen that class conditions were still not conducive. When the researcher explained the subject matter there were still some students who were walking and chatting with their friends so that the learning process became disturbed. The observation of the second cycle of the second meeting showed that some students had begun to be able to follow the learning process better than the first meeting. But there are still some students who joke with their friends, making students a little noisy. From the results of observations, it shows that the collaboration of students in the learning process is increasing. Some students have begun to work together to solve student's worksheet questions. The responsibility of students has also begun to appear.

Based on the implementation of the action, the results of observations and interviews in the first cycle showed that student collaboration had improved but was still not optimal, so that reflection was carried out between researchers and mathematics teacher class VIII C on the results of observation as material to determine the action in cycle II. In the first observation of the second cycle, the students enthusiastically participated in the learning and the class situation had begun to be conducive. Students begin to be active, it can be seen from students that they have begun to dare to ask material that is not yet understood and when the discussion begins to be confident to answer the questions of their friends. The second meeting showed that some students had begun to be able to participate in the learning process better than the first meeting. From the results of observations, it shows that the collaboration of students in the learning process is increasing.

In the first cycle, the mathematics learning process was carried out using the NHT type cooperative learning model. The collaboration of students in this learning has begun to increase. This can be seen from the percentage of each indicator of student collaboration, which is positive interdependence of $55.56 \%$ with sufficient criteria, individual responsibility is $64.58 \%$ with good criteria, promotive interaction between students is $55.21 \%$ with sufficient criteria, communication between members of $53.47 \%$ with sufficient criteria, group processing carried out at $58.33 \%$ with sufficient criteria. With the number of students whose collaboration in the criteria is not very good, there are 11 good criteria for students, there are 9 criteria for adequate students, there are 5 criteria for lack of students, and the criteria for once less is 1 student. Obtained the average percentage of observations of collaboration in mathematics learning at $57.29 \%$. This means that in accordance with the qualifications the results of the percentage of the score of observation of the students' collaboration in mathematics learning in the first cycle included the criteria for enough.

In the second cycle after correcting deficiencies in the first cycle, the collaboration of students in the process of learning mathematics using the NHT type cooperative learning model has increased. This can be seen from the percentage of each indicator of student collaboration namely positive interdependence of $73.33 \%$ with good criteria, the individual responsibility of $74 \%$ with good criteria, promotive interaction of $70 \%$ with good criteria, communication between members by $70 \%$ with criteria well, group processing is $68 \%$ with good criteria. With the number of students in collaboration in the 
criteria, there are very good 3 students, the criteria are good there are 22 students, the criteria are quite nonexistent, the criteria are not available, and the criteria are very low there is 1 student. Obtained the percentage of the average observation results of collaboration in mathematics learning at $71 \%$. This means that in accordance with the qualifications the results of the percentage of the observation scores of the students' collaboration in mathematics learning in the second cycle are categorized as Good. The observation results of student collaboration in the mathematics learning process in cycle I and cycle II can be seen in Table 3 below.

Table 3. Results of Student Cooperation Observation Sheet in Mathematics Learning in Cycle I and Cycle II

\begin{tabular}{|c|l|c|c|c|}
\hline \multirow{2}{*}{ No } & \multirow{2}{*}{ Indicator } & \multicolumn{2}{c|}{ Percentage } & \multirow{2}{*}{ Information } \\
\cline { 3 - 4 } & & Cycle I & Cycle II & \\
\hline 1 & Positive Addiction & $55,56 \%$ & $73,33 \%$ & Increase \\
\hline 2 & Individual Responsibility & $64,58 \%$ & $74 \%$ & Increase \\
\hline 3 & Promotive Interaction & $55,21 \%$ & $70 \%$ & Increase \\
\hline 4 & Inter-Member Communication & $53,47 \%$ & $70 \%$ & Increase \\
\hline 5 & Group Processing & $58,33 \%$ & $68 \%$ & Increase \\
\hline
\end{tabular}

From table 3 it can be seen that the collaboration of students in mathematics learning on each indicator always increases in each cycle. In this study, in addition to using observational data, researchers also used data in the form of interviews conducted with students. Interviews were conducted to determine students' responses regarding mathematics learning using the NHT type cooperative learning model. Based on the results of the interview obtained the following results.

1. Positive responses from students to the learning process using the NHT type cooperative learning model.

2. By using the NHT type of cooperative learning model, students become more enthusiastic and enthusiastic in participating in mathematics learning.

In addition, for the results of the daily replication test it also increases in each cycle, this can be seen in Table 4 below. 
Table 4. Improvement of Cycle I and Cycle II Daily Test Results

\begin{tabular}{|l|c|c|c|}
\hline \multicolumn{1}{|c|}{ Daily results } & Cycle I & Cycle II & Information \\
\hline Total value for each cycle & 1605 & 1945 & Increase \\
\hline Average & 64,2 & 77,8 & Increase \\
\hline The highest score & 90 & 100 & Increase \\
\hline Lowest value & 35 & 50 & Increase \\
\hline Many students complete & 9 & 18 & Increase \\
\hline Many students have not yet finished & 16 & 7 & Increase \\
\hline Students' percentages complete & $36 \%$ & $72 \%$ & Increase \\
\hline
\end{tabular}

The results of the above data indicate that the research objectives have been achieved in the second cycle, the results of the study indicate an increase in each indicator of cooperation. Therefore research is considered complete and dismissed in cycle II. So that overall it can be concluded that the implementation of mathematics learning using the NHT type cooperative learning model can improve student collaboration in the learning process of mathematics in class VIII C SMP Muhammadiyah 2 Minggir Sleman Regency in the odd semester of the 2015/2016 academic year.

\section{CONCLUSIONS}

Based on the research that has been carried out on grade VIII C odd semester SMP Muhammadiyah 2 Minggir Sleman Yogyakarta Academic Year 2015/2016 on the subject matter of straight-line equations can be concluded that using the NHT cooperative learning model can improve student collaboration in the mathematics learning process. This is evident from the results of the observation sheet of student collaboration in the mathematics learning process which experienced an increase in the percentage of indicators of cooperation in each cycle, namely positive interdependence in the first cycle of $55.56 \%$ and second cycle $73.33 \%$. Individual responsibility in cycle I was $64.58 \%$ and cycle II was $74 \%$. Promotive interactions in the first cycle were $55.21 \%$ and cycle II $70 \%$. Communication between members in the first cycle was $53.47 \%$ and the second cycle was $70 \%$. Group processing in the first cycle was $58.33 \%$ and the second cycle was $68 \%$. The increase in the average percentage on each indicator of student cooperation as a whole in the first cycle amounted to $57.29 \%$ and in the second cycle was $71 \%$. The criteria of the average indicator of cooperation in the first cycle reached sufficient criteria and in the second cycle reached the criteria of good.

\section{REFERENCES}

Arikunto, Suharsimi, Suhardjono, dan Supardi. 2007. Penelitian Tindakan Kelas. Jakarta : Bumi Aksara. Arikunto, Suharsimi. 2013. Prosedur Penelitian. Jakarta : Rineka Cipta.

Arikunto, Suharsimi dan Cepi Safruddin Abdul Jabar. 2014. Evaluasi Program Pendidikan. Jakarta : PT Bumi Aksara.

Pemerintah Republik Indonesia.2003.UU Republik Indonesia nomor 20 Tahun 2003 Tentang Sistem Pendidikan Nasional.Jakarta : Pemerintah Republik Indonesia.

Purwanto, M.Ngalim. 2013. Prinsip-prinsip dan Teknik Evaluasi Pengajaran. Bandung: PT Remaja Rosdakarya. 